DOI: $10.1515 /$ pts-2014-0032

PHYSICAL AND TECHNICAN ENERGY PROBLEMS

\title{
CHARGING OF THE ELECTRIC VEHICLES IN PRIVATE SECTOR: TECHNICAL AND ECONOMIC ASPECTS
}

\author{
L.Grackova $^{1}$, I.Oleinikova ${ }^{2}$, G.Klavs ${ }^{1}$ \\ ${ }^{1}$ Laboratory of Energy System Analysis and Optimisation, \\ ${ }^{2}$ Smart Grid Research Centre \\ Institute of Physical Energetics \\ 21 Aizkraukles Str., Riga, LV-1006, LATVIA \\ e-mail: energy@edi.lv
}

\begin{abstract}
The economic aspect considered in the work is related to the charging of an electric vehicle (EV) at a single private house when this is done every day. To perform the relevant cost estimation it was necessary to determine: the average annual electricity consumption under the condition of everyday charging an EV and the average electricity consumption off the mains for covering a distance of $100 \mathrm{~km}$ by an EV and the time in hours for its charging. Comparison is made for the day-time intervals from which it is possible to choose the preferable for proper loading the electric line and the most beneficial for the consumer. Under analysis are two EV connection scenarios for 100 individual households from which $10 \%, 20 \%$ and $30 \%$ have EVs, with 8 -h duration of each charging at the current of $13 \mathrm{~A}$. The authors consider the consumption and electric energy payment packages which - with planned opening of the electric energy market on January 1, 2015 - will offer the clients the enterprises rendering services on the electric energy sale.
\end{abstract}

Keywords: electric vehicles (EV), distribution networks, household.

\section{INTRODUCTION}

Ever growing concern about the environmental pollution and instable prices of oil forced the manufacturers of cars to invest substantial financial means in the development of commercial production of electric vehicles. This, in turn, affected favourably the number of motor vehicle models available to potential customers.

For a long time, the main deterrent factors for production and distribution of electric vehicles (EVs) were the high cost, small kilometrage on a single charge, absence of the infrastructure for public charging, and low consumer demand. By now, the efforts of producers of EVs, storage batteries and chargers have exerted a positive influence on the respective demand and public opinion.

Currently, also in Latvia the interest in electric vehicles could be seen. First two vehicles of the type were registered at the Road Traffic Safety Directorate (CSDD) in July 2011 [1]. Within three years their number has risen up to 56. The number of public charge points in the territory of Latvia already exceeds ten, and it is 
evident that the market of electric vehicles and the infrastructure for public charging stations will broaden ${ }^{1}$.

In 2014, the Ministry of Environmental Protection and Regional Development of the Republic of Latvia, using the financial means provided by the National Climate Change programme has announced a project competition for greenhouse gas emissions reduction in the transport sector, according to which it is planned to open by $2023^{2}$ at least 235 charge stations for electric vehicles.

Therefore, it is of primary importance to study all aspects of the EV running. Our work is devoted to the technical and economic aspects of EV charging as related to a single private household.

\section{DESCRIPTION OF THE TASK}

To solve our particular task it was necessary:

- To determine the average annual electricity consumption by a single private household under the condition of everyday charging of an electric vehicle.

- To study separate daily time intervals for charging an electric vehicle so that it is possible to choose the interval that would be preferable - both technically and economically - from the viewpoint of loading the electrical network.

- To consider the cost of electrical energy for potential EV owners.

Note: in the cases when these owners are living in multi-storeyed houses it is reasonable to charge their electric vehicles at the public stations. Therefore, in this paper only a private residential sector is considered.

\section{Charging of electric vehicles off the mains}

The parameters of the charger to be used for EV charging in private houses (Mode 2 / Type 2 Charging Station Alternating Current (AC)) are the following: the one-phase mains, AC voltage $230 \mathrm{~V}, 10 \mathrm{~A}, 13 \mathrm{~A}$ and $16 \mathrm{~A}$, the maximum power up to $3.7 \mathrm{~kW}$. Depending on the current value and weather conditions, the charging of an electric vehicle can take from $6 \mathrm{~h}$ to $16 \mathrm{~h}$.

\section{Available models of electric vehicles}

A wide enough market for electric vehicles in Latvia allows the purchaser to choose the preferable model. The data in Table 1 are given only for five models of electric vehicles which are capable of covering $80-175 \mathrm{~km}$ on a single charge.

Table 1

Models of electric vehicles

\begin{tabular}{|l|l|l|l|l|l|}
\hline & $\begin{array}{l}\text { Nissan } \\
\text { LEAF [2] }\end{array}$ & $\begin{array}{l}\text { Mitsubishi } \\
\text { iMiev [3] }\end{array}$ & $\begin{array}{l}\text { Fiat Fiorino } \\
\text { Elettrico [4] }\end{array}$ & $\begin{array}{l}\text { Volkswagen } \\
\text { e-up [5] }\end{array}$ & $\begin{array}{l}\text { Opel Am- } \\
\text { pera [6] }\end{array}$ \\
\hline $\begin{array}{l}\text { Electric battery } \\
\text { capacity, kWh }\end{array}$ & 24 & 16 & 20.7 & 11.7 & 16 \\
\hline $\begin{array}{l}\text { Kilometrage per } \\
\text { charge, km }\end{array}$ & 175 & 150 & 100 & 100 & 80 \\
\hline
\end{tabular}

'http://www.latvenergo.lv//lat/iepirkumi_konkursi_piedavajumi/e_transporta_uzlades_ punktu_karte/

${ }^{2} \mathrm{http} / / /$ www.varam.gov.lv/lat/darbibas_veidi/KPFI/?doc=17874 
Based on manufacturers' specifications and taking into account real data on servicing and charging electric vehicles that are sold and serviced in Latvia, calculations have been performed for the average electricity consumption off mains required for covering a distance of $100 \mathrm{~km}$ by one $\mathrm{EV}$. In the calculations it was assumed that in a private house a charger Mode 2 / Type 2, 13A, 230V AC (1-phase), $\max 3.0 \mathrm{~kW}$ is installed.

According to the manufacturers' data sheets, the charge of EV battery should be $19.4 \mathrm{kWh}$ on average for a $100 \mathrm{~km}$ travel [7]. However, the real data obtained in servicing and charging an EV of the FIAT Fiorino Elettrico model are indicative of the necessity to take into account the cable losses at electric energy transmission as well as the seasonal weather conditions. Further calculations have shown that to cover a distance of $100 \mathrm{~km}$ the electric vehicle is to consume off mains: $21.5 \mathrm{kWh}$ in winter, $21.3 \mathrm{kWh}$ in spring/autumn, and $19.6 \mathrm{kWh}$ in summer.

\section{Time of charging an electric vehicle}

Relying upon the information on consumption off mains, the number of hours required for charging a storage battery is calculated by the formula:

$$
h=\frac{B C_{s}}{I_{c h}}
$$

where $B C s$ is the battery capacity $(\mathrm{kWh})$, i.e. its charging the battery charge depending on season (winter, spring, summer, autumn);

$I_{c h}$ is the current of charger (A).

As a result, at the average indicators assumed, the time for charging an EV off mains to ensure a trip of $100 \mathrm{~km}$ is: $7.4 \mathrm{~h}$ in winter, spring, and autumn, and 6.8 $\mathrm{h}$ in summer.

The information on the average electric energy consumption off mains by an electric vehicle and on its charging time makes it possible to estimate the daily load for a statistically average private house of the type.

\section{Load estimation}

Estimation of the 24-h load for a single private house under the condition that in this house - besides the day-to-day electricity consumption by household appliances - everyday full charge of the EV battery takes place. The estimation is performed in three stages:

Stage 1: determination of the average annual and daily consumption by one private house which is based on the use of household appliances. At this stage under analysis are the load schedules for all seasons as well as for working days and weekends.

Stage 2: determination of the average annual electricity consumption by the same private house provided there occurs everyday EV charging. For this procedure the optimal time interval is analyzed and selected.

Stage 3: selection of the interval within 24-h time for EV charging, which is preferable - both technically and economically - for the network load schedule. 
The calculation of the average annual and daily consumption by one private house where only household appliances consume electricity is done based on statistical data on the annual electric energy consumption by private houses located in Riga and Jurmala which are connected either to one-phase or three-phase network. In such houses (floor space 125-150 $\mathrm{m}^{2}$ ) typically a 3-5-member family lives all the year round; in the house an electric stove and a gas-fuelled boiler are installed. Analysis of the data has shown that the average annual consumption by one private house makes up $3934 \mathrm{kWh}$ [8].

Next, the average daily consumption values were calculated and load schedules were worked out for all seasons, working days and weekends. Figures 1 and 2 illustrate the average daily seasonal consumption: $11.8 \mathrm{kWh}$ in working days, 12 $\mathrm{kWh}$ at weekends; in spring and autumn $11.2 \mathrm{kWh}$ in a working day, $11.6 \mathrm{kWh}$ in a day-off; in summer $8.1 \mathrm{kWh}$ in a working day, and $9.2 \mathrm{kWh}$ in a day-off. It can also be seen that the maximum electricity consumption takes place in winter.

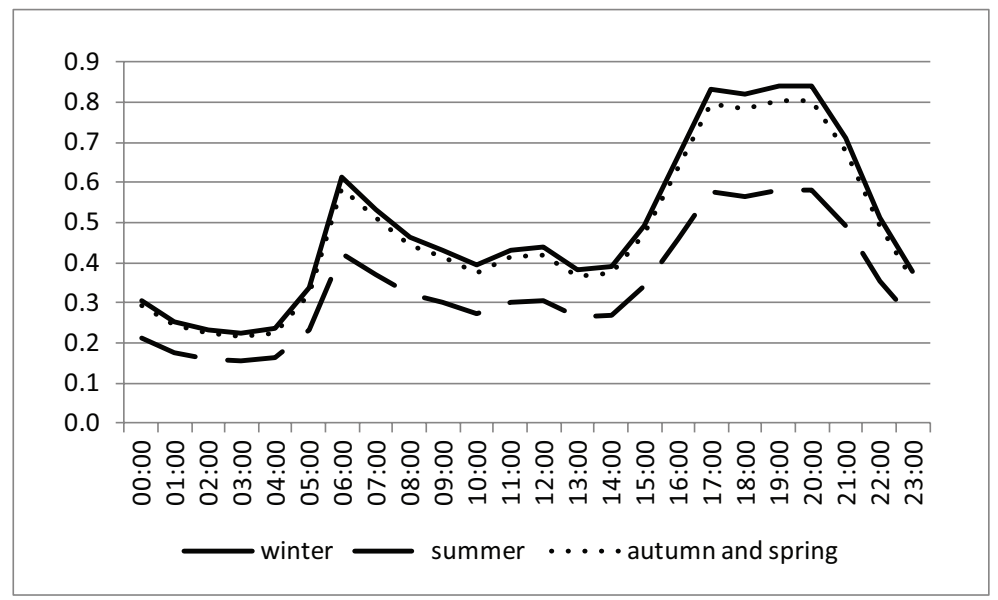

Fig.1. Seasonal electricity consumption profile in a working day, $\mathrm{kW}$

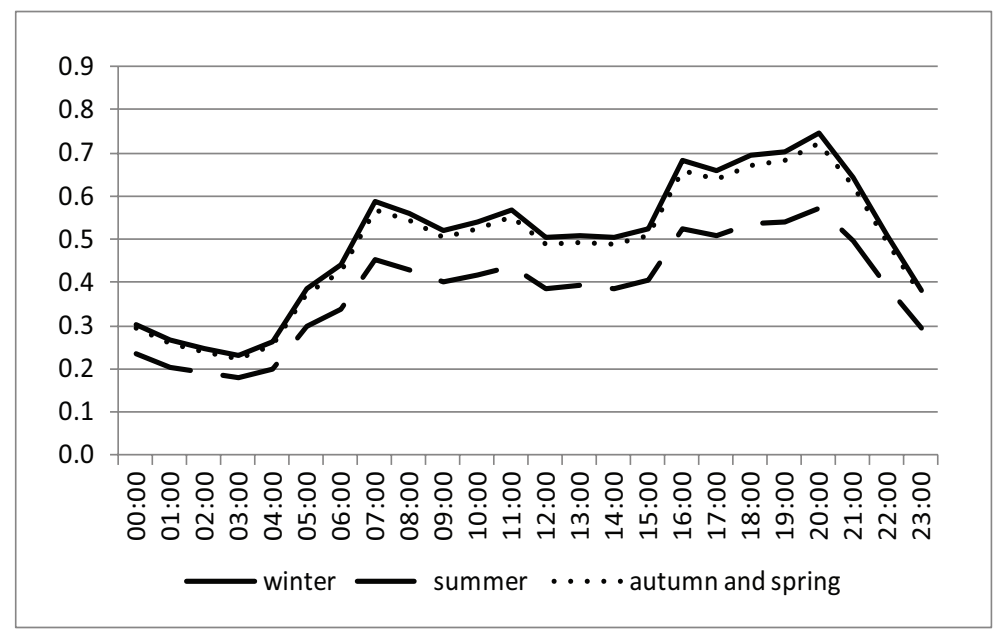

Fig.2. Seasonal electricity consumption profile at weekends, $\mathrm{kW}$ 
Comparison of the autumn-spring seasonal schedules with the winter one shows that the consumption in autumn-spring decreases insignificantly: by $4.3 \%$ in a working day, and by $3.1 \%$ at weekends. In the summer season, the comparative decrease is significant: by $30.8 \%$ in a working day, and by $23 \%$ at weekends.

As concerns the daily consumption peaks, they are independent of seasons, and exist through the whole year: in a working day from 6:00 to 8:00 and from 16:00 to 21:00, while in a day-off - from 7:00 to 11:00 and from 16:00 to 21:00.

To define the degree of non-uniformity of the load schedules we will find the relevant load factor, which shows how many times the electric energy consumption in a given day is smaller than that to be consumed if the load is maximal all the time. Such being the case, the load factor is in the range $0.58-0.67$ for all seasons.

\section{Electricity consumption at different times}

In a similar way all these indices are considered at the second stage for a private house where in addition to the day-to-day electricity consumption by household appliances also everyday full charge of an EV battery occurs.

The calculations have shown that in this case the average annual consumption will grow almost three times, making up $11598 \mathrm{kWh}$. In turn, we obtain the following increase for the average daily consumption: in winter $33.3 \mathrm{kWh}$ in a working day and up to $33.5 \mathrm{kWh}$ at weekends; in spring and autumn up to $32.5 \mathrm{kWh}$ in a working day and up to $32.9 \mathrm{kWh}$ at weekends; in summer up to $27.7 \mathrm{kWh}$ in a working day and up to $28.8 \mathrm{kWh}$ at weekends.

Next, we studied the daily load schedules in the working days and at weekends by seasons, in different time intervals: from 18:00 to 02:00, from 20:00 to 04:00, from 23:00 to 07:00, and from 08:00 to 16:00.

It was revealed that charging of an electric vehicle raises the average daily load several times. Figure 3 shows this load for a working day in winter when in the time interval 00:00-05:00 the maximum growth is observed - more than 10 times.

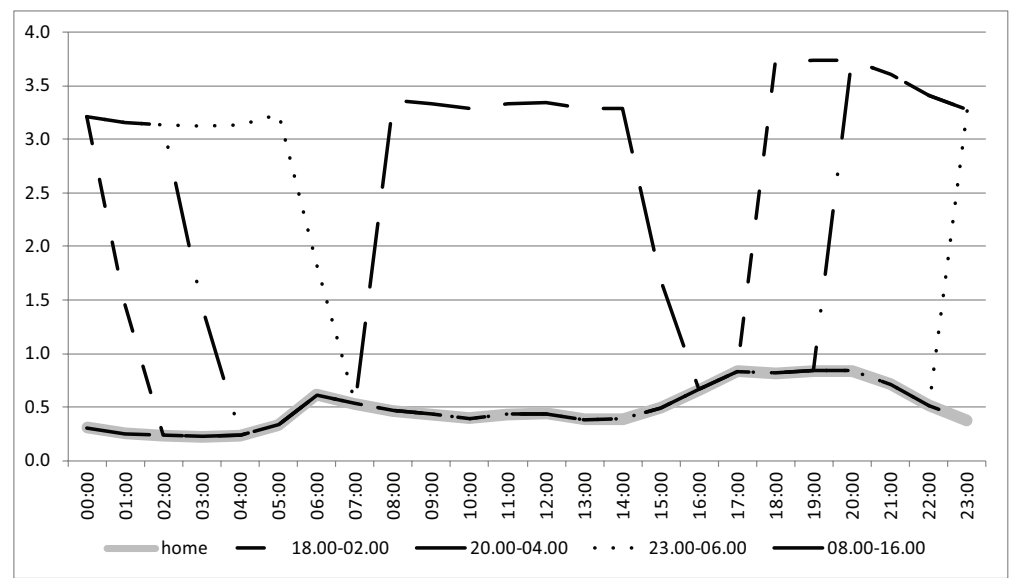

Fig. 3. Comparative profiles of electricity consumption in a winter working day: home and home+EV

The load factor for all seasons ranges from 0.33 to 0.43 (see Table 2). This testifies that the EV charging enhances the non-uniformity of load schedule. 
Seasonal and daily load factors for a single private house

\begin{tabular}{|l|l|c|c|c|}
\hline & & Winter & Autumn and Spring & Summer \\
\hline \multirow{2}{*}{ 18:00-02:00 } & working day & 0.37 & 0.37 & 0.33 \\
\cline { 2 - 5 } & weekend & 0.38 & 0.38 & 0.35 \\
\hline \multirow{2}{*}{ 20:00-04:00 } & working day & 0.37 & 0.37 & 0.33 \\
\cline { 2 - 5 } & weekend & 0.38 & 0.38 & 0.35 \\
\hline \multirow{2}{*}{ 23:00-07:00 } & working day & $\mathbf{0 . 4 2}$ & $\mathbf{0 . 4 2}$ & $\mathbf{0 . 3 7}$ \\
\cline { 2 - 5 } & weekend & $\mathbf{0 . 4 3}$ & $\mathbf{0 . 4 2}$ & $\mathbf{0 . 3 8}$ \\
\hline \multirow{2}{*}{ 08:00-16:00 } & working day & 0.41 & 0.41 & 0.36 \\
\cline { 2 - 5 } & weekend & 0.40 & 0.40 & 0.36 \\
\hline
\end{tabular}

The non-uniform load schedule of a single object with low consumption does not affect considerably the general load schedule of an individual district network, since it is the sum of consumers' load schedules.

\section{Case study}

To further analyze the results it was necessary to study the daily load schedules in a district with a typical model of distribution network (schematically shown in Fig. 4) which supplies electric energy to 100 individual households. Some of them, in addition to the day-to-day electricity consumption by household appliances also perform everyday full charge of an electric vehicle.

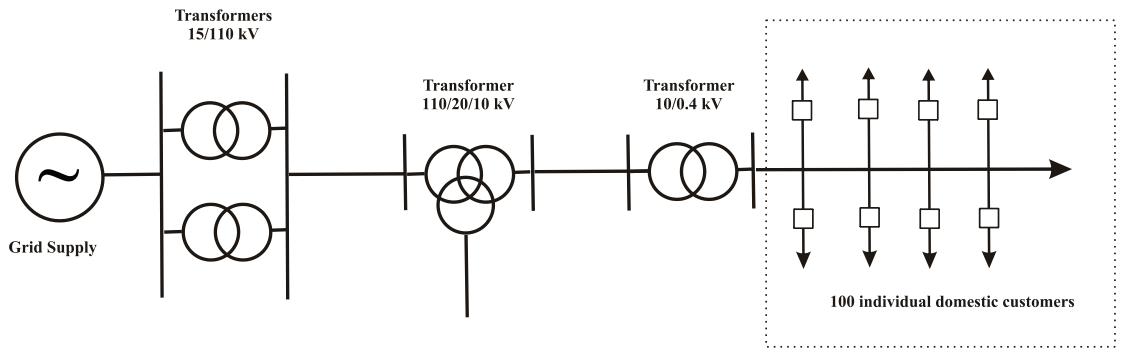

Fig. 4. A typical model of distribution network

\section{SCENARIOS}

The research data given above show that the maximum demand for electric energy is observed in a working day in winter. To make further estimations, the corresponding load profile is chosen and the relevant scenarios of EV connection are formed assuming that $10 \%, 20 \%$ and $30 \%$ of houses have electric vehicles which are charged within eight hours at 13A (AC). Two scenarios of EV charging were determined, which are as follows.

Scenario 1. The time of charging implies that the consumers have no justified incentives to connect their vehicles at a definite time. Therefore, this will be done as soon as they return to their homes from work, for example: from 18:00 to 01:00, from 20:00 to 03:00, and from 23:00 to 07:00 (Fig. 5).

Scenario 2. The time of charging implies that the consumers are interested in 
the connection of their vehicles at a definite time. This will be done in the interval of time from 23:00 to 07:00 (Fig. 6).

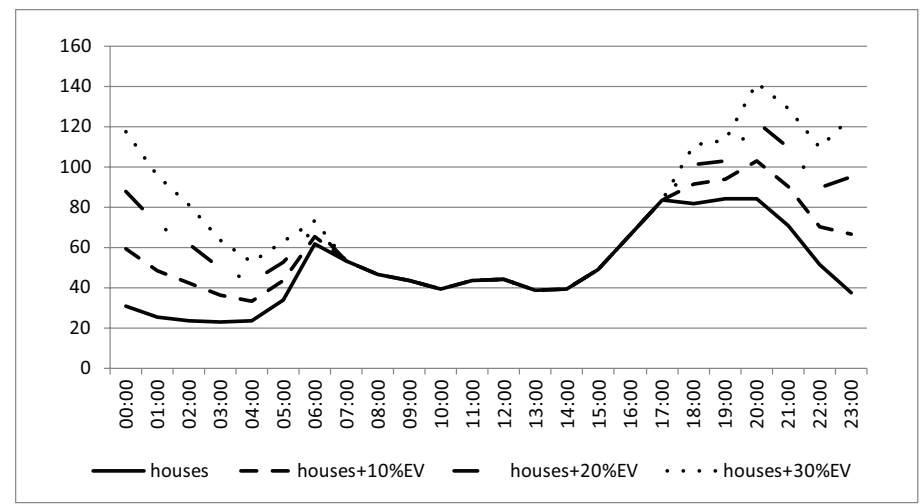

Fig. 5. Scenario 1 of EV charging

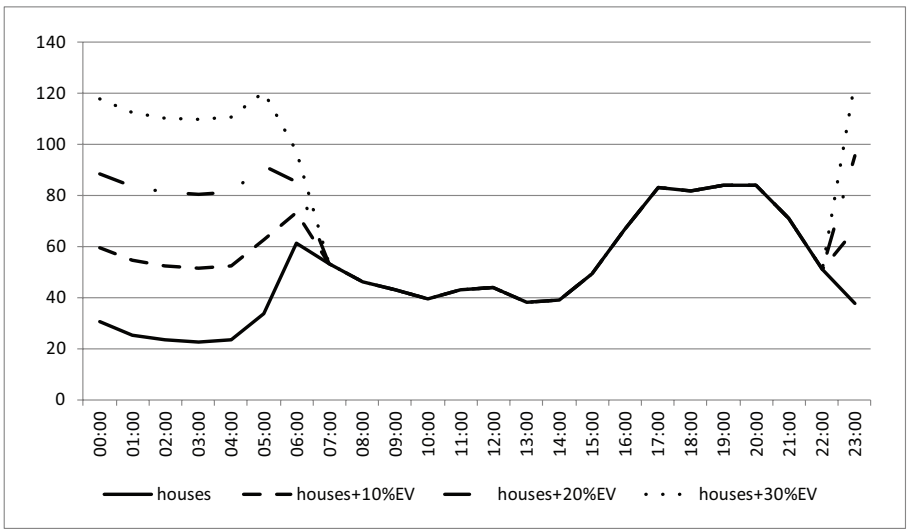

Fig. 6. Scenario 2 of EV charging

\section{RESULTS AND DISCUSSION}

The results obtained evidence that the time of EV charging does not affect the overall average daily electric energy consumption, since the additional daily load is one and the same.

As seen from Fig. 5, which illustrates graphically Scenario 1, in the cases when the consumers have no justified incentives to connect their vehicles at a definite time, the existing morning and evening peak loads are increasing still further. For every $10 \%$ of the houses with electric vehicles the morning peak load increases by $2.5 \%$, while the evening one - by $12.2 \%$.

As the result of EV charging according to Scenario 2, for every $10 \%$ of the houses with electric vehicles the existing morning peak load increases by $7.5 \%$, while the evening one remains as before, which means that on the whole the load schedule profile becomes better (see Fig. 6).

Comparison of load factors for the two scenarios (Fig. 7) points to the following: 
In compliance with Scenario 1 this factor decreases from 0.58 to 0.53 , i.e. the non-uniformity of the load schedule is expressed even more.

In compliance with Scenario 2 - in the case when $10 \%$ or $20 \%$ of households are charging their vehicles - the load factor increases from 0.58 to 0.73 . In turn, when $30 \%$ of households have electric vehicles this factor decreases to 0.63 , which means that to retain the degree of load schedule non-uniformity the number of electric vehicles should not exceed a definite limit.

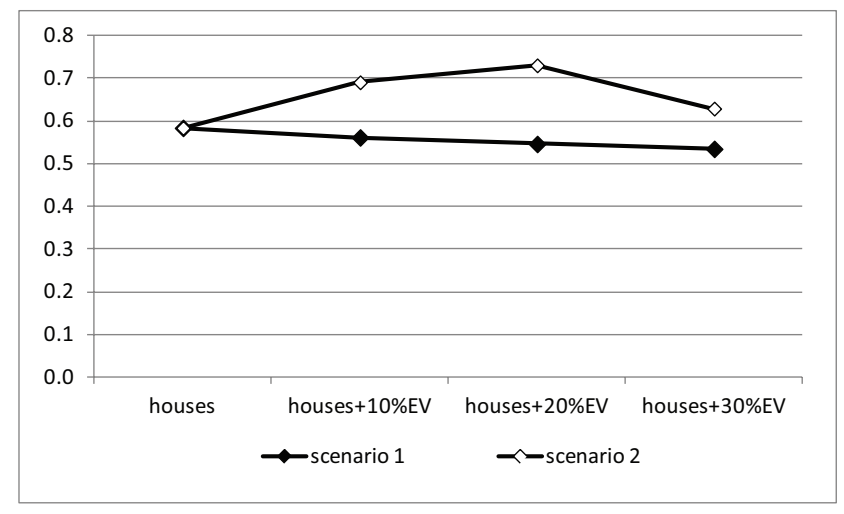

Fig. 7. Load factors in two scenarios

\section{COSTS OF ELECTRICITY FOR DOMESTIC EV CHARGING}

From January 1, 2015 on, in Latvia the accepted changes in regulations will become valid according to which all consumers of electric energy - households included - will buy it in a free market. As for now, six companies have made offers to the private electricity consumers.

Since the majority of Latvian residents are clients of $\mathrm{J} / \mathrm{S}$ Co. Latvenergo, from these offers only those of the Elektrum produkti ${ }^{3}$ concerning the consumption of and payments for electric energy were considered.

The analysis set forth in this paper as to the average annual consumption by a single private house (household) possessing an electric vehicle has given the value of $967 \mathrm{kWh}$ for its average monthly consumption.

After consideration of the whole package of $\mathrm{J} / \mathrm{S}$ Co. Latvenergo, we have come to the conclusion that its clients who are going to acquire or have already acquired a vehicle with electric motor it is preferable to choose two packages: Elektrum Izdevīgais 200+ and Elektrum Izdevīgais 600+. A distinctive feature of these packages is that they provide two tariffs on the electric energy that take into account either one or two time zones. The one-zone tariff implies that the cost of $1 \mathrm{kWh}$ will not change depending on the day-night time and on the weekday. In turn, the tariff taking into account two time zones depends on the day-night time and on the weekday. This means that for the electricity consumed from 07:00 to 23:00 the client pays by one tariff, while from 23:00 to 07:00 (i.e. at night) as well as weekends and holidays (round the clock) the cheaper tariff comes into force. The tariff with account

${ }^{3}$ www.e-latvenergo.lv/lv/private/produkti/ 
taken for two time zones is beneficial for the client only in the case if more than $60 \%$ of consumption occurs from 23.00 to 07.00 and in weekends/holidays.

The householder who has an electric vehicle and chooses the tariff with one time zone will pay from 0.1631 to 0.1646 EUR for $1 \mathrm{kWh}$. In this case the EV will be charged within the time that would be convenient for the owner. In turn, if such a householder prefers the tariff taking into account two time zones this cost will be from 0.1445 to 0.1459 EUR (Table 3). A disadvantage of this choice is that the vehicle will be charged only within the time interval from 23:00 to 07:00, and only weekends/holidays - at any time.

When these two offers are compared, it becomes apparent that the packages with two tariff zones are more beneficial, since they allow reducing the monthly expenses by $\sim 12 \%$.

Therefore, it is more economical to charge the electric vehicles from 23:00 to 07:00 and at any time weekends/holidays.

Table 3

Electricity costs offered by Elektrum Izdevīgais 200+ and Elektrum Izdevīgais 600+ (J/S Co.

Latvenergo)

\begin{tabular}{|l|l|l|}
\hline & $\begin{array}{l}\text { Elektrum Izdevīgais 200+, } \\
\text { costs per month (per 1 kWh), } \\
\text { EUR }\end{array}$ & $\begin{array}{l}\text { Elektrum Izdevīgais 200+, } \\
\text { costs per month (per 1 kWh), } \\
\text { EUR }\end{array}$ \\
\hline For one-time zone & $159.12(0.1646)$ & $157.72(0.1631)$ \\
\hline For two-time zones & $141.04(0.1459)$ & $139.76(0.1445)$ \\
\hline
\end{tabular}

\section{CONCLUSIONS}

The conclusion based on estimation of the daily load schedules in a district with a typical model of distribution network from which 100 individual household consumers are supplied with electric energy is as follows.

For the individual household it is preferable to charge its electric vehicle from 23:00 to 7:00, which allows the monthly electricity costs to be reduced by $12 \%$ owing to the two-tariff payment system.

It is obvious that the owner of a private house will form appropriate habits of electric energy consumption only due to optimal beneficial tariffs.

Also of importance is that the implementation of these schemes would be favourable for the functioning of distribution network, since at a definite (the optimal) number of simultaneously charged electric vehicles the non-uniformity of daily load schedule decreases (although with load peaks normally existing).

\section{REFERENCES}

1. www.csdd.lv/lat/noderiga_informacija/statistika/transportlidzekli/

2. www.nissan.lv

3. www.mitsubishi-motors.lv

4. www.micro-vett.it

5. www.emobility.volkswagen.com/lv 
6. www.autoblitz.lv

7. Grackova, L., Oleinikova, I. (28-30 May, 2014). Economic motivation for electric vehicles participation in power market. In: The 11th International Conference on the European Energy Market, (EEM 2014). Krakow (Poland). Category numberCFP1452DUSB; Code 106830. Article number: 6861224.

8. www.latvenergo.lv/portal/page/portal/Latvian/Sad_tikls/Tipveida+grafiki_jauns.htm

\title{
ELEKTROAUTOMOBIĻU LĀDĒŠANAS PRIVĀTĀS MĀJĀS TEHNISKIE UN EKONOMISKIE ASPEKTI
}

\author{
L.Gračkova, I.Oḷeinikova, G.Klāvs
}

K o p s a vi $1 \mathrm{ku} \mathrm{m} \mathrm{s}$

Šajā rakstā tiek analizēts vidējais diennakts elektroenerğijas patēriņš un diennakts slodzes grafiki privātmājās apstākḷos, kad privātmājas īpašnieki lādē elektroautomobili katru dienu vidējam brauciena attālumam $100 \mathrm{~km}$. Elektroautomobiḷa uzlādes režīmi tiek analizēti, ņemot vērā patēriņa elektriskās slodzes grafika kvalitāti raksturojošos rādītājus un patērētāja ekonomiskos ieguvumus.

Lai novērtētu ekonomiski stimulētu patērētāju elektroautomobiḷa uzlādes laika izvēles ietekmi uz diennakts elektriskās slodzes aizpildījuma koeficientu, tika izveidoti un analizēti 2 scenāriji, kas apraksta 100 privātmāju ar dažādu elektroautomobiḷu piederības īpatsvaru divas atšksirīgas automobiļu uzlādes gadījumus.

08.12 .2014 